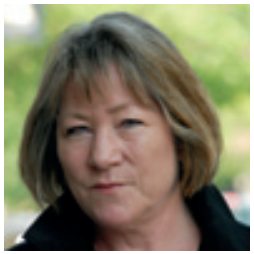

\title{
Fanget inn i det amerikanske helsevesenet
}

\author{
Ikke feiler jeg noe særlig, og lege kan \\ jeg gå til når jeg er hjemme på ferie \\ i Norge. Men ved hjelp av tilfeldighe- \\ ter er jeg nå blitt fanget inn i det ame- \\ rikanske helsevesenet - og det kan gi \\ noen hver frisk bakoversveis.
}

Det begynte med en kraftig influensa for halvannet år siden i California. Jeg fikk anbefalt en lege med kontor rett bortenfor kontoret vårt - dermed var jeg fanget.

Legen driver en moderne legepraksis der mye av konsulteringen foregår på nett. Men først må du altså ha møtt ham, for han krever at du én gang i året gjennomfører en større helseundersøkelse. Så der kom jeg med influensaen, fikk utskrevet mine piller og ble presentert for en regning så stiv at jeg trodde det måtte være noe galt. Over 1200 kroner for at han på kort tid kunne konstatere det jeg allerede visste, nemlig at jeg hadde influensa og trengte antibiotika. Dette var bare begynnelsen.

Systemet i USA er slik at man må ha helseforsikring for å være sikret behandling uten altfor store utgifter. Den kjøper man selv eller får gjennom arbeidsgiver. Det er så dyrt at det nå finnes rundt 50 millioner amerikanere som ikke har forsikring. Disse får dermed et høyst mangelfullt helsestell. For utlendinger gjelder egne regler. Jeg må betale regningene fullt ut, men får refundert utleggene fordi jeg betaler en viss andel til folketrygden hjemme.

Jeg hadde nesten glemt hele legen da det 2-3 måneder etter influensaen kom en e-post: «Som du vet har du forpliktet deg til en årlig helsesjekk som en del av ditt forhold til meg, og jeg vil at du kommer hit og gjennomgår det så fort som mulig.» Jeg tenkte et par blodprøver, blodtrykksmåling og en prat. Og slik ble det. Etter et par dager fikk jeg en insisterende e-post: «Jeg liker ikke prøveresultatene dine - du må komme tilbake med en gang.» Han pepret meg med høyt kolesterolinnhold i blodet, høyt blodtrykk og høye sukkerverdier. Midt i faresonen for hjerteinfarkt, slag og det som verre er. Jeg begynte å føle meg virkelig dårlig, og han begynte å skrive ut resepter. Først medisin mot høyt kolesterol. Så var det blodtrykket. Jeg vet hvor høyt et ideelt blodtrykk skal være, og mitt er bare marginalt høyere enn det. Han forsøkte seg med piller mot dette også, men jeg nektet. For sukkerinnholdet i blodet ville han sende meg til en spesialist.

Jeg dro til spesialisten, som ikke kunne fortelle meg annet enn det den andre legen allerede hadde fortalt meg. Jeg fikk beskjed om at medisiner ikke var nødvendig. Fett honorar, takk - rundt ett tusen kroner her og et par bortkastede timer. På dette stadiet i min legehistorie hadde jeg betalt over 12000 kroner. Ennå har jeg ikke helt skjønt hva som foregår. Jeg er litt satt ut av legens gjentakelser av at jeg virkelig er i faresonen. Flere undersøkelser ble foreslått. Jeg måtte på stresstest for å undersøke hjertet og ble satt på en tredemølle. Sakte først, og så fortere og fortere. Båndet på tredemøllen gikk virkelig ikke særlig fort. «Hvorfor kalles det stresstest?» spurte jeg. «For å se hvor mye du og hjertet ditt tåler,» sa damen. «Men jeg tåler da mye mer enn dette,» sa jeg. «Ja, du har bestått testen med bravur,» svarte damen. Og jeg betalte nok en fet regning.

Nå begynte jeg å krangle med legen, som ville finne ut om jeg feilte mer. Undersøkelse av endetarmen var hans neste forslag. Etter hvert kom det frem at han selv er spesialist på dette - og at han gjerne ville utføre undersøkelsen selv. 2000 dollar skulle det koste - 1000 til legen, 1000 til klinikken der undersøkelsen skulle utføres.
Jeg nektet. Ikke tale om, selv om pengene ville bli refundert. Han foreslo øyelege. Hvorfor det? Nei, man vet vel aldri. Jeg forsøkte å si at jeg ser bedre enn de fleste, men han hørte ikke på det øret. Hva med beinskjørhet? Finnes det i familien? Jeg burde absolutt undersøke beintettheten. Jeg sa nei igjen. Og han begynte å skjønne at det han nok har betraktet som en melkeku av en pasient kanskje ikke ville bli så lukrativ likevel.

Jeg er vant til at leger bryr seg om min helbred, ikke om hvor mye penger de kan tjene på meg. Gjennom møtet med legen ble jeg klar over at i kapitalismens høyborg er også helsetjenester bygd på profitt. De aller fleste av min leges pasienter har helseforsikring, og forsikringsselskapene ville aldri latt en pasient gå igjennom det jeg har vært igjennom av undersøkelser på så tynt grunnlag.

Jeg har vært på en del møter om president Barack Obamas helsereform. Obama vil blant annet gi forsikringsselskapene konkurranse. Ikke så rart når forsikringsdirektører har lønn på godt over 10 millioner dollar og forsikringsselskaper betaler astronomisk utbytte til aksjonærene - mens forsikringene for folk flest har steget tre ganger så mye som prisene ellers de siste årene.

I Washington sitter legen min og håver inn. Han bor flott midt i byen og har samtidig leilighet i Miami. Etter en av våre krangler sa jeg til ham: «Tenk om du tok all profitten fra forsikringsselskapene, kuttet legenes priser og medisinprodusentenes enorme fortjeneste - da kunne du fătt litt av et helsevesen.» «Du sier noe,» sa legen.

\section{Sinnette Groth}

I neste nummer:

Psykogene ikke-epileptiske anfall

Venekirurgi

Molekylær lymfomdiagnostikk
Kurs i klinisk kommunikasjon

Mødredødelighet 